\title{
Stimulating Erythropoiesis: Future Perspectives
}

\author{
Ashraf Mikhail ${ }^{a}$ Adrian Covic $^{c}$ David Goldsmith ${ }^{b}$ \\ a Renal Unit, Morriston Hospital, Swansea, and ${ }^{\mathrm{b}}$ Renal Unit, Guy's Hospital, London, UK; \\ 'Parhon Hospital, lasi, Romania
}

\section{Key Words}

Anaemia - Cytoprotection - Erythropoiesis-stimulating agent $\cdot$ Erythropoietin

\begin{abstract}
The introduction of recombinant human erythropoietin (rHuEpo) nearly 20 years ago has revolutionised the management of patients with CKD, providing the opportunity for safe long-term anaemia correction without the attendant risks identified with blood products. Based on our expanding knowledge in this area, there are many exciting and innovative new approaches to anaemia correction that stand on, or are close to, the threshold of yielding products ready for clinical use. Recently, an Epo-related molecule called continuous Epo receptor activator has been licensed in Europe, and other molecules are in various processes of development, including Epo mimetic peptide. The search goes on for orally active antianaemic therapies, and several strategies are being investigated. Furthermore, it is now clear that in addition to the anaemia-correction properties of erythropoiesis-stimulating agents, there is the potential for cytoprotection by prevention of cellular apoptosis. This effect could be used in the prevention of ischaemia-reperfusion injury as well as other conditions associated with acute kidney injury and other disease processes. The aim of this article is to discuss these possible future strategies, focusing in particular on those with a reasonable likelihood of a pharmaceutical product that is likely to be used clinically.
\end{abstract}

Copyright $\odot 2008$ S. Karger AG, Basel

\section{KARGER}

Fax +4161306 1234

E-Mail karger@karger.ch

www.karger.com (c) 2008 S. Karger AG, Basel

$1420-4096 / 08 / 0314-0234 \$ 24.50 / 0$

Accessible online at:

www.karger.com/kbr

\section{Introduction}

The introduction of recombinant human erythropoietin (rHuEpo) nearly 20 years ago has revolutionised the management of patients with chronic kidney disease (CKD), providing the opportunity for safe long-term anaemia correction without the attendant risks identified with blood products. The success of this strategy in CKD has slowly allowed anaemia associated with other chronic conditions (e.g. diabetes, heart failure, cancer chemotherapy) to be also tackled. This led the way to the use of this approach to correct anaemia in other chronic disease states.

Anaemia correction improves cognitive function, quality of life, exercise capacity and cardiac function in patients with CKD $[1,2]$. Presently, an increasing number of patients with CKD and nearly every patient on renal replacement therapy (RRT) will receive an erythropoiesis-stimulating agent (ESA). While currently available ESAs have proved pivotal in achieving better correction of anaemia, the current treatment strategies are limited by some serious shortcomings. These include the complexity and high cost of manufacture, strict requirements for correct storage and administration, non-convenient routes of administration (subcutaneous and intravenous, but not oral), and toxicity/immunogenicity. As a result, much effort continues to be spent to advance other techniques to achieve anaemia correction. Over the last decade, our understanding of the molecular mechanism of

Dr. Ashraf Mikhai

Renal Unit, Morriston Hospital

Swansea SA6 6NL (UK)

Tel. +44 1792702 222, Fax +44 1792703716

E-Mail ashraf.mikhail@swansea-tr.wales.nhs.uk 
the action of Epo has improved significantly. Based on our expanding knowledge in this area, there are many exciting and innovative new approaches to anaemia correction that stand on or are close to the threshold of yielding products ready for clinical use.

The aim of this article is to introduce the reader to possible potential avenues for future management of anaemia in CKD rather than providing future therapeutic recommendations (table 1). We focus in particular on those mechanisms with a reasonable likelihood of a clinically useful product. In addition, we will discuss different methods by which science is trying to develop strategies and products that may address the limitations of the currently available ESAs.

\section{Biosimilar Erythropoietin}

A generation of biotechnology-derived therapeutic agents are reaching the end of their patent lives, heralding the market entry of biosimilars. Recently, the Committee for Medicinal Products for Human Use has given a favourable opinion of two biosimilar epoetins, alfa (HX575) and zeta, and both are now licensed in the EU. Nevertheless, recombinant proteins are associated with a number of issues which distinguish them from traditional chemical drugs and their generics. Recombinant proteins are highly complex at the molecular level, and biological manufacturing processes are highly elaborate: they involve cloning, selection of a suitable cell line, fermentation, purification, and formulation. In addition, the therapeutic properties of recombinant proteins are highly dependent on each step of the manufacturing process. Since the manufacturing process will be different from that used by the innovator, concerns about the safety, efficacy and consistency of the clinical effects may be a limiting factor in the licensing/marketing of future biosimilar Epos [3]. Of particular concern is the potential immunogenicity of biosimilars. The immunogenicity of therapeutic protein is influenced by several factors such as protein sequence, the presence of exogenous or endogenous epitopes, and the degree to which glycosylation influences the exposure of antigenic sites and their solubility. In addition, immunogenicity is also influenced by formulation and storage, downstream processing, and the level of impurity or presence of contaminants. Since most of these factors are influenced by the ESA manufacturing process, the immunogenicity of biosimilars could be totally unrelated to the reference product. Even when biosimilars are produced from the same genetic construct, using the same technique, formulation and packaging as the innovator product, there is no guarantee that they are comparable with the reference product. In addition, assessing the immunogenicity of biopharmaceuticals lacks international standardisation. When a biopharmaceutical has unique determinants, antibody assays become highly product specific. Another problem is that quality assurance assays for the immunogenicity of biopharmaceuticals are difficult to establish. A typical example is the immunogenicity profile published in the HX575 European Public Assessment Reports (EPAR), where a transient binding antibody response was seen in a number of intravenously treated renal failure patients in the pivotal trial. The response was noted among patients treated with either the innovator and/or the biosimilar product [4]. That response has never been experienced previously in any of the previous studies involving innovator ESAs [for a full review on biosimilars, please refer to NDT vol. 21, suppl. 5].

\section{Epoetin Delta}

Contrary to currently available Epos, which are produced from Chinese hamster ovary cell line, epoetin delta is produced from a human cell line. Phase III studies have shown that epoetin delta is effective in maintaining $\mathrm{Hb}$ values at between 10 and $12 \mathrm{~g} / \mathrm{dl}$ for up to 24 weeks when administered intravenously three times a week in hemodialysis patients [5], and subcutaneously 1-3 times a week in predialysis patients [6].

\section{Long-Acting Erythropoiesis-Stimulating Agents}

CERA (continuous erythropoietin receptor activator; created by F. Hoffmann-La Roche, Ltd.) is a new long-acting agent with an extended duration of action. Its design is prompted by previous knowledge that modification of proteins with amphiphilic polymers can result in an increased half-life, although the properties may vary with the number and size of the polymer molecules attached [7]. CERA is created by integrating a large polymer chain into the epoetin molecule, thus increasing the molecular weight to twice that of epoetin at approximately $60 \mathrm{kDa}$. This methoxy-polyethylene glycol polymer chain is integrated via amide bonds between the $\mathrm{N}$-terminal amino group or the $\varepsilon$-amino group of lysine (predominantly lysine-52 or lysine-45), using a single succinimidyl buta- 
Table 1. Possible future agents in anaemia management

\begin{tabular}{|c|c|c|c|c|c|c|}
\hline Product & Mechanism of action & $\begin{array}{l}\text { Route of } \\
\text { administration }\end{array}$ & $\begin{array}{l}\text { Develop- } \\
\text { ment stage }\end{array}$ & $\begin{array}{l}\text { Anticipated } \\
\text { marketing } \\
\text { authorisation }\end{array}$ & Potential advantages & Limitations \\
\hline $\begin{array}{l}\text { Biosimilar } \\
\text { epoetins }\end{array}$ & $\begin{array}{l}\text { recombinant human } \\
\text { Epo }\end{array}$ & s.c./i.v. & phase III-IV & 2007 & ? cheaper & $\begin{array}{l}\text { quality/ } \\
\text { immunogenicity }\end{array}$ \\
\hline Epoetin delta & $\begin{array}{l}\text { recombinant human } \\
\text { Epo }\end{array}$ & s.c./i.v. & phase III-IV & 2007 & ? once weekly dosing & $\begin{array}{l}\text { no extra advantage over } \\
\text { available epoetins }\end{array}$ \\
\hline CERA & $\begin{array}{l}\text { Epo-methoxy-poly- } \\
\text { ethylene glycol polymer }\end{array}$ & i.v./s.c. & phase IV & 2007 & $\begin{array}{l}\text { long-acting: continuous sustained } \\
\text { effect }\end{array}$ & $\begin{array}{l}\text { long acting: difficult to } \\
\text { terminate effect once } \\
\text { administered }\end{array}$ \\
\hline Hematide & Epo mimetic peptide & i.v./s.c. & phase II-III & 2010 & $\begin{array}{l}\text { - long-acting: continuous } \\
\text { sustained effect } \\
\text { - ? usefulness in patients with } \\
\text { Epo-induced PRCA }\end{array}$ & $\begin{array}{l}\text { long acting: difficult to } \\
\text { terminate effect once } \\
\text { administered }\end{array}$ \\
\hline FG-2216 & $\begin{array}{l}\text { prolyl hydroxylase } \\
\text { inhibitor (HIF stabiliser) }\end{array}$ & oral & phase II & $?$ & $\begin{array}{l}\text { - stimulation of endogenous } \\
\text { erythropoietin } \\
\text { - improved iron utilisation } \\
\text { - ? usefulness in inflammation/ } \\
\text { Epo hyporesponsiveness }\end{array}$ & ? long-term safety \\
\hline FG-4592 & $\begin{array}{l}\text { prolyl hydroxylase } \\
\text { inhibitor (HIF stabiliser) }\end{array}$ & oral & phase II & $?$ & $\begin{array}{l}\text { - stimulation of endogenous } \\
\text { erythropoietin } \\
\text { - improved iron utilisation } \\
\text { - ? usefulness in inflammation/ } \\
\text { Epo hyporesponsiveness }\end{array}$ & ? long-term safety \\
\hline CTNO 528 & $\begin{array}{l}\text { Epo mimetic anti- } \\
\text { body fusion protein }\end{array}$ & i.v./s.c. & phase I & $?$ & $\begin{array}{l}\text { ? usefulness in patients with } \\
\text { Epo-induced PRCA }\end{array}$ & ? long-term safety \\
\hline $\begin{array}{l}\text { Aerosolized } \\
\text { Epo }\end{array}$ & Epo-IgG Fc aerosol & inhalation & phase I & $?$ & easy to deliver & $\begin{array}{l}\text { - variable bioavailability } \\
\text { - ? consistency of } \\
\text { pharmacological effect }\end{array}$ \\
\hline $\begin{array}{l}\mathrm{HCP} \\
\text { inhibitors }\end{array}$ & HCP inhibitors & oral & preclinical & $?$ & $\begin{array}{l}\text { ? usefulness in Epo } \\
\text { hyporesponsiveness }\end{array}$ & ? long-term safety \\
\hline K11706 & GATA inhibitors & oral & preclinical & $?$ & $\begin{array}{l}\text { ? usefulness in inflammation/ } \\
\text { Epo hyporesponsiveness }\end{array}$ & ? long-term safety \\
\hline Oral Epo & (mucoadhesive tablet) & oral/buccal & preclinical & $?$ & easy to deliver & $\begin{array}{l}\text { - variable bioavailability } \\
\text { - ? consistency of } \\
\text { pharmacological effect }\end{array}$ \\
\hline Gene therapy & $\begin{array}{l}\text { gene manipulation: } \\
\text { - plasmid transfer } \\
\text { - hypoxia-dependent } \\
\text { AAV gene therapy } \\
\text { - gene switch } \\
\text { - antigen-driven B } \\
\text { cell-mediated Epo- } \\
\text { methoxy-polyethylene } \\
\text { glycol polymer }\end{array}$ & $\begin{array}{l}\text { gene transfer/ } \\
\text { i.v./s.c. }\end{array}$ & $\begin{array}{l}\text { preclinical/ } \\
\text { phase III }\end{array}$ & $?$ & $\begin{array}{l}\text { - ? cure of anaemia of renal/ } \\
\text { chronic disease } \\
\text { - long acting: continuous sustained } \\
\text { effect }\end{array}$ & $\begin{array}{l}\text { - ? ability to adjust Epo } \\
\text { delivery to physiologic } \\
\text { demands } \\
\text { - long acting: difficult to } \\
\text { terminate effect once } \\
\text { administered }\end{array}$ \\
\hline
\end{tabular}

noic acid linker [8]. Polyethylene glycols (PEGs) are a group of water-soluble polymers of varying molecular weights. When linked covalently to proteins, PEGs alter protein properties in ways that extend their potential uses. Changing the size of the polymer could generate different preparations of varying molecular weights and plasma half-lives. Integration of a large polymer into the epoetin molecule could have two important advantages: first, reduction of immunogenicity [9]. In keeping with this is the finding that none of the patients that participated in phase III trials of CERA $(n>2,000)$ developed anti-Epo or anti-CERA antibodies. The second ad- 
Fig. 1. Erythropoietin mimicry. a EpoEPOR interaction. Activation of EPOR occurs when oligomerization of receptor chains is induced by binding of the Epo molecule to a specific ligand-binding domain on EPOR. b, c Using random phage display library and receptor affinity purification, a small peptide molecule, with no structural similarity to Epo, capable of stimulating EPOR is created. To prolong the polypeptide biological duration of action, the peptide is PEGylated. Changing the molecular size of the polymer could yield peptide preparations with variable half-lives.

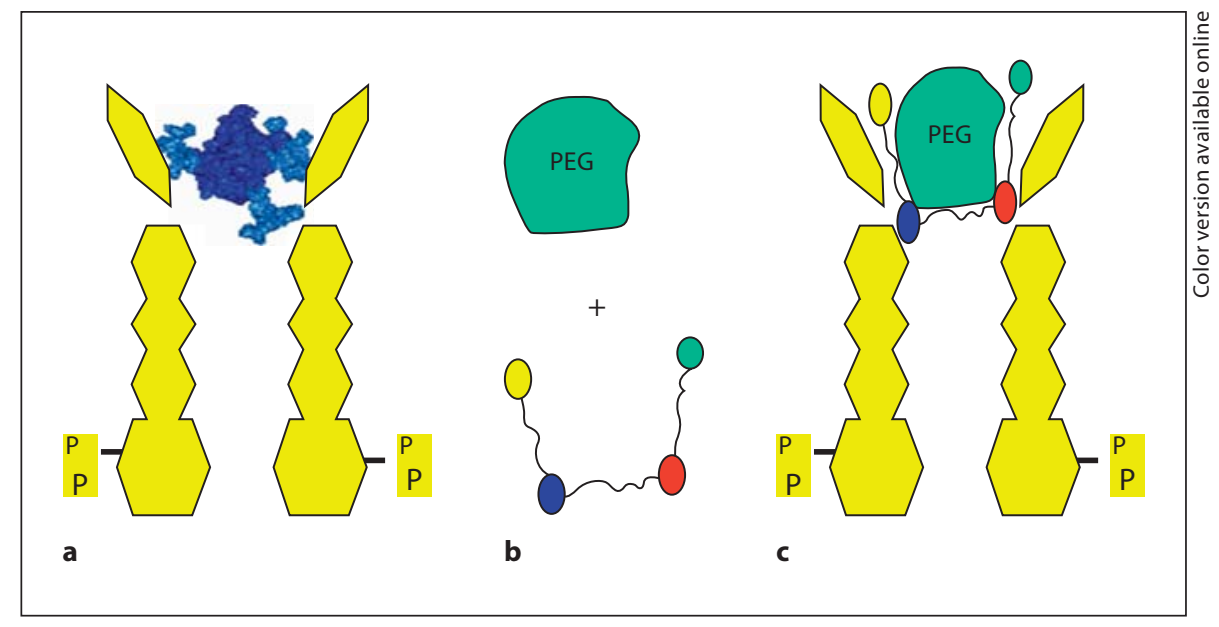

vantage of PEGylated Epo is its unique pharmacodynamic properties. Plasmon resonance biosensor (Biacore ${ }^{\circledR}$, Biacore AB, Freiburg, Germany) studies have shown that CERA has a 50-fold lower binding affinity when compared to epoetin beta, but its dissociation rate is much faster. This specific binding constant of CERA permits attachment to the Epo receptor (EPOR) and stimulation of erythropoiesis, followed by rapid dissociation from the receptor rather than internalisation. It also leads to a higher concentration of CERA at the receptor site compared to epoetin [10]. These data suggest that CERA has receptor-binding and pharmacokinetic properties that give rise to a more potent stimulation of erythropoiesis in vivo than epoetin, with regard to both the magnitude and the duration of response [11].

Pharmacokinetic studies have demonstrated a prolonged serum half-life of CERA (mean $134 \mathrm{~h}$ for the i.v. route and $139 \mathrm{~h}$ for the s.c. route). The clearance of the drug (given via either route) was low and, more importantly, no drug accumulation was observed when a steady state was achieved using different frequencies [12]. A multicenter phase II study assessed the effect of CERA in rHuEpo-naïve patients with CKD but not on dialysis. A dose-dependent, frequency-independent response to CERA treatment was observed. Erythropoietic responses to CERA were sustained until the end of the study (18 weeks) for all the CERA dose groups [13]. Similar observations were obtained in a phase II multicenter study in 61 haemodialysis patients [14].

Phase III clinical trials have shown that CERA once every 2 weeks corrects anaemia in CKD patients who are or are not on dialysis, whereas once-monthly CERA maintains stable haemoglobin levels when patients are directly converted from the more frequent epoetin or darbepoetin- $\alpha$ administration $[15,16]$. There has been no evidence of antibody development in any patient treated with CERA so far.

PEGylated products are eliminated, mainly unmetabolised, via the biliary and urinary routes. Toxic doses cause liver and renal damage. Nevertheless, toxicity of PEGylated product is extremely unlikely to develop clinically since exposures from PEGylated proteins are at least 600 -fold lower than the toxic dose [17]. Attempts at integrating naturally occurring polymers into Epo molecules could be an attractive alternative to PEGylated Epo. PolyXen, created by Lipoxen and based on polysialic acid, is a naturally occurring polymer which is biodegradable, non-immunogenic and non-toxic. Phase I clinical trials on the PolyXen-Epo complex are currently underway.

\section{Erythropoietin Mimicry}

Using random phage display libraries and receptor affinity purifications, it was possible to isolate a group of small peptides with no structural homology to the endogenous Epo molecule that act as full agonists of the EPOR [18]. Mimetic polypeptides have a shorter plasma half-life in circulation compared to native proteins. Such a limitation can be overcome by combining the polypeptide to a polymer (e.g. PEG) (fig. 1).

\section{Hematide}

Hematide (created by Affymax) is synthetic PEGylated peptide-based ESA with a completely novel a mino acid 
sequence that is totally unrelated to Epo or to any other known naturally occurring human sequences.

Results of a phase I study demonstrated that single intravenous doses $(0.025,0.05$, and $0.1 \mathrm{mg} / \mathrm{kg})$ of hematide resulted in dose-dependent increases in circulating reticulocytes in 28 healthy volunteers, with clinically and statistically significant increases in red blood cells from baseline, an effect sustained for at least 4 weeks [19]. A phase II, open-label dose-finding study examined the safety and pharmacodynamics of hematide in ESA-naïve CKD patients not on dialysis. Sixty patients with baseline $\mathrm{Hb}$ values 9-11 g/dl received a subcutaneous injection of hematide once every 4 weeks for up to 6 doses. The reticulocyte count peaked at about 2 weeks after each injection. Correction of anaemia $(\mathrm{Hb}>11 \mathrm{~g} / \mathrm{dl})$ was achieved in 24 of $30(80 \%)$, and 29 of 30 (97\%) patients by 4 and 8 weeks of treatment, respectively. Subsequent doses maintained $\mathrm{Hb}$ values in the target range for up to 6 months [20]. Phase III studies are currently underway in the USA and Europe.

Similar to CERA, hematide seems promising and may have several potential advantages over currently available ESAs, including prolonged half-life and pharmacodynamic activity with an expected dosing interval every 3 4 weeks [20]. Hematide, being a peptide-based molecule, may stimulate the production of human anti-hematide antibodies, but such antibodies are unlikely to cross-react with endogenous Epo or any other ESAs, therefore giving them the potential for treatment of patients with pure red cell aplasia.

The pharmacodynamic advantage of longer-acting preparations (hematide and CERA) could also be a potential limitation. The longer elimination half-life could be an important factor in the management of patients with accidental overdose or those developing drug-related side effects. While it is common clinical practice to omit one dose of shorter-acting ESAs in patients developing some drug-related side effects (hypertensive emergencies, abnormally high $\mathrm{Hb}$ ), it is not clear how such conditions would be managed when longer-acting preparations come into clinical practice.

\section{Non-Peptide Mimetics}

Attempts at designing orally active ESAs have led to designing small non-peptide molecules capable of supporting the in vitro proliferation of Epo-responsive cells. Several compounds have been created, but their EPOR affinity and biological activity were much lower than those of native Epo. Although they did not materialise into clinical application, such findings show that small, orally active molecules with interesting potential do exist [21].

\section{Fusion Peptides}

A fusion protein, consisting of two complete human Epo domains linked in tandem by a 17-amino acid flexible peptide, showed a high affinity to EPOR and a greatly enhanced in vitro and in vivo activity compared with rHuEpo. It has also been found that the length of the peptide linker separating the two Epo domains could influence the activity of the biological molecule. Increasing the length of the linker resulted in reduction of the activity of the molecule to a level comparable to that of $\mathrm{rHu}-$ Epo [22].

Since GM-CSF is required for early erythropoiesis prior to the expression of EPOR (stimulation of the burstforming unit erythroid, BFU-e), another dimeric fusion protein composed of a GM-CSF-Epo complex was capable of inducing erythropoiesis in cynomolgus monkeys [23]. Unfortunately, that molecule was later found to induce anti-Epo antibodies and severe anaemia as well [24].

\section{CTNO 528}

One strategy to increase a therapeutic protein half-life is to modify the fate of proteins within the target cell. The fusion of therapeutic proteins to albumin or the Fc region of an antibody, in addition to increasing the effective molecular weight of the protein, promotes recycling out of the cell upon endocytosis via the $\mathrm{Fc}$ and albumin recycling receptors, so these strategies are particularly useful for enhancing the serum half-life of therapeutic proteins $[25,26]$.

CTNO 528 (Centocor) is an erythropoiesis mimetic antibody fusion protein with no structural similarity to rHuEpo. Rats treated with a single subcutaneous dose of CTNO 528 showed a longer-lasting reticulocytosis and $\mathrm{Hb}$ rise compared with treatment with rHuEpo or darbepoetin. CTNO 528 was also effective in correcting anaemia in rat models of pure red cell aplasia [27]. A phase I study in healthy males showed that a single intravenous dose of CTNO 528 produced a dose-dependent increase in reticulocyte count and in $\mathrm{Hb}$ concentration (maximum effect days 8 and 22, respectively). In addition, there was a dose-dependent increase in soluble transferrin receptor and endogenous Epo levels (the latter is probably due to competitive EPOR binding). None of the 24 treated subjects developed antibodies to CTNO 528 [28]. 


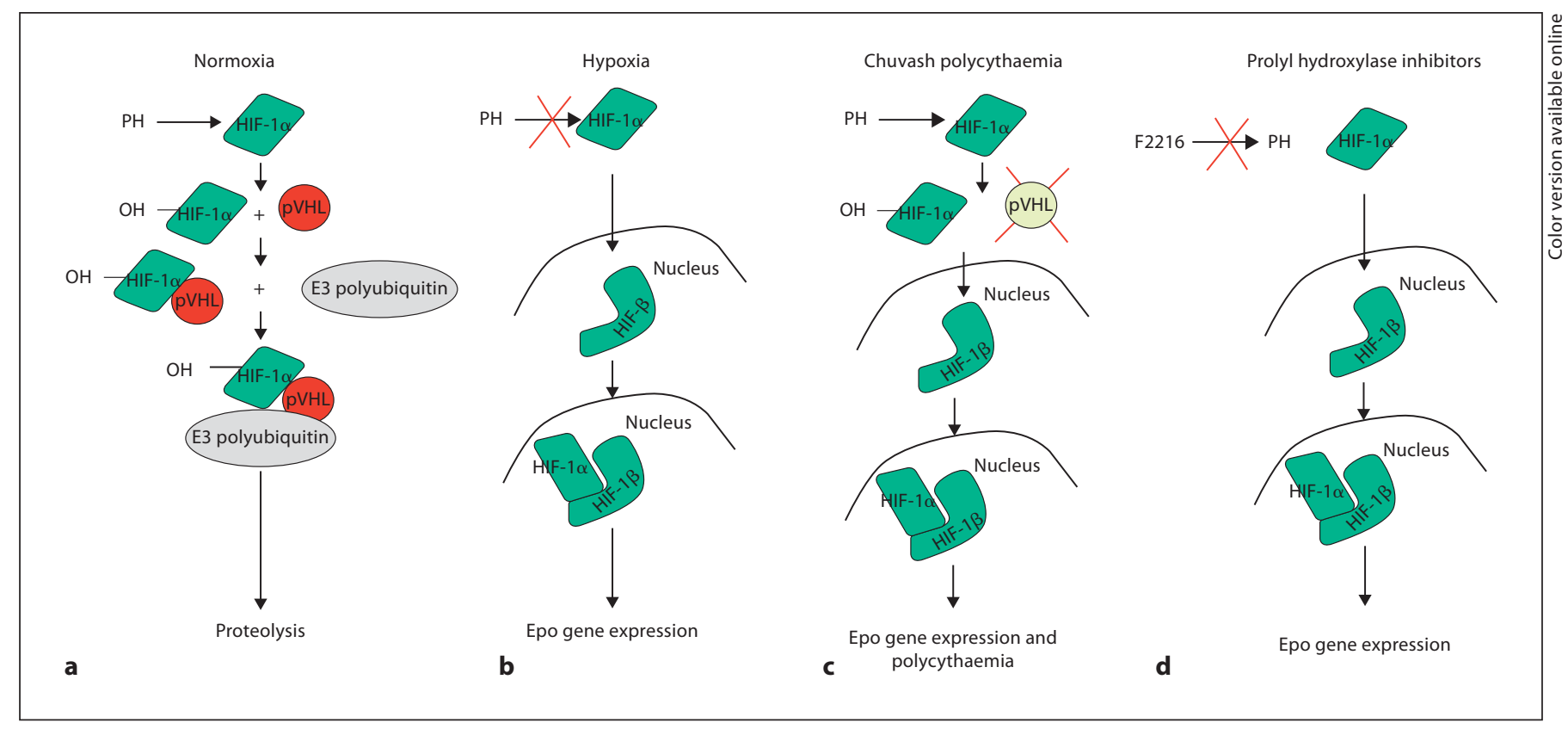

Fig. 2. Oxygen sensing. a In normoxia HIF-1 $\alpha$ is hydroxylated by cytoplasmic proline hydroxylase (which requires iron and 2-oxoglutarate for its action). Prolyl hydroxylated HIF-1 $\alpha$ combines with von-Hippel-Lindau gene product (pVHL). The HIF-1 $\alpha$ / pVHL product forms a complex with E3 polyubiquitin. The resulting polyubiquitinated HIF- $1 \alpha$ is subsequently hydrolysed by proteosomes. b In hypoxic conditions, prolyl hydroxylase is inactivated, and, subsequently, HIF-1 $\alpha$ is protected from degradation and is enabled to enter the nucleus to form a heterodimer with the nuclear HIF-1 $\beta$, resulting in gene transcription. c In Chuvash polycythaemia, a defective pVHL results in elevated HIF- $1 \alpha$ levels under normoxic conditions, and increased Epo gene expression results in polycythaemia. d Inhibition of PHI by F2216 protects HIF- $1 \alpha$ against hydroxylation resulting in increased Epo gene expression.

\section{Increasing Epo Gene Expression}

An exciting tool to treat anaemia of chronic disease could be by simply increasing Epo expression. In persons with normal renal function, plasma Epo levels are inversely proportional to $\mathrm{Hb}$ concentrations. Several regulatory DNA sequences and transcription factors act as modulators of the Epo gene expression, e.g. the hypoxia response element HRE, the GATA family, and HCP (SHP1) inhibition.

Epo gene expression is stimulated by a decrease in arterial oxygen tension (e.g. high altitudes) or when oxygen affinity of the blood increases. The key regulatory DNA sequence that acts as an oxygen sensor is HRE, composed of nucleotide sequences to which HIF (a heterodimer composed of two subunits, $\alpha$ and $\beta$ ) can bind. Both HIF$1 \alpha$ and HIF- $1 \beta$ are continuously being produced. HIF- $1 \beta$ is protected from degradation by cytoplasmic proteolytic enzymes by its sequestration within the nucleus. Under normoxia, HIF-1 $\alpha$ is hydroxylated by cytoplasmic pro- line hydroxylase $(\mathrm{PH})$, which requires iron and 2-oxoglutarate for its action. Prolyl hydroxylated HIF-1 $\alpha$ is recognised and tagged with the von Hippel-Lindau gene product (pVHL). The HIF-1 $\alpha /$ pVHL product forms a complex with E3 polyubiquitin. The resulting polyubiquitinated HIF-1 $\alpha$ is subsequently hydrolysed by proteosomes (fig. 2a) [29]. Under hypoxic conditions, $\mathrm{PH}$ is inactivated, HIF- $1 \alpha$ is therefore protected from degradation and is enabled to enter the nucleus to form a heterodimer with the nuclear HIF-1 $\beta$, and as a result the expression of such genes as those coding for glucose uptake, glycolytic enzymes, and growth factors like Epo or vascular endothelial growth factor (VEGF) is upregulated (fig. 2b) [30, 31].

Genetic mutation in the HIF-1 $\alpha$ regulatory pathway could result in congenital polycythaemia. A typical example is seen in patients with Chuvash syndrome, a disorder characterised by a homozygous mutation $(598 \mathrm{C}>\mathrm{T})$ of the VHL gene [32]. Although endemic to the Chuvash population of Russia, this mutation occurs worldwide 
and originates from a single ancient genetic event [33]. In that condition, as a result of mutation of the VHL gene, pVHL is defective and as a result, the HIF-1 $\alpha$ level is elevated under normoxic conditions leading to congenital polycythaemia in those affected (fig. 2c). In a matched cohort retrospective mortality and cross-sectional morbidity study, involving 96 patients with Chuvash polycythaemia, VHL 598C $>$ T homozygosity was associated with vertebral hemangiomas, varicose veins, lower blood pressures, and elevated serum VEGF concentrations, as well as premature mortality related to cerebral vascular events and peripheral thrombosis. While the $\mathrm{Hb}$-adjusted serum Epo concentrations are approximately 10-fold higher in those affected than in healthy controls, their Epo response to hypoxia remains unaffected [34]. Spinocerebellar haemangioblastomas, renal carcinomas, and pheochromocytomas typical of classical VHL syndrome were not found. These data suggest that overexpression of HIF-1 $\alpha$ and VEGF in Chuvash polycythaemia is not sufficient to cause the tumorigenesis observed in patients with the classical VHL syndrome, since the VHL protein has some other yet unidentified substrates than HIF, that may have roles in the growth and behaviour of cells [35, 36].

\section{Prolyl Hydroxylase Inhibitors (PHIs)}

Several orally active PHIs are being developed and are under clinical trials by FibroGen. A small phase II clinical trial has shown that one PHI, FG-2216, given orally twice a week, corrects anaemia in ESA-naïve CKD patients, and maintains the $\mathrm{Hb}$ level in those treated previously with Epo. These results suggest that CKD patients can produce Epo in response to $\mathrm{PHI}$ despite renal damage and fibrosis. The circulating levels of endogenous Epo induced by PHIs were much lower than the levels reported in patients treated with ESAs [37]. In addition, these preparations may improve erythropoiesis by modulating iron metabolism. In one study involving another PHI (FG-4592), treatment was reported to dramatically reduce abnormally high levels of hepcidin back to normal and restore the natural balance in iron regulation in an experimental model of inflammation-induced anaemia [38]. The downregulation of hepcidin by PHI prevents ferroportin degradation and leads to the improvement of iron mobilization from storage sites for bone marrow utilization.

Although PH inhibition could stabilize not only HIF$1 \alpha$ but a host of other proteins as well, it is possible that such a potential will not have a clinically significant effect in patients receiving long-term therapy with PHIs, since the stabilization of HIF by PHIs is similar to that observed in patients with Chuvash syndrome (fig. 2d). Nevertheless, multicentre studies are necessary to investigate the safety of PHIs in clinical practice.

\section{GATA Transcription Factors}

The GATA family consists of six transcription factors, GATA1-6. They are categorised as a family due to the fact that they all bind to the DNA consensus sequence (A/T)GATA(A/G) by two characteristic zinc-finger motifs specific to the GATA family [39]. The GATA family is divided into two subfamilies on the basis of their expression profiles. GATA1-3 belong to the haematopoietic subfamily [40]. GATA-2 is expressed prior to the formation of the blood islands of the mammalian yolk sac and plays a role in the maintenance of the pleuripotent stem cells of the haematopoietic system [41]. GATA-2 inhibits Epo gene transcription by binding to the GATA sequence on the Epo promoter, thereby leading to the downregulation of Epo mRNA expression, and subsequent Epo synthesis, in response to hypoxia [42]. GATA2 therefore acts as a negative regulatory molecule of Epo gene expression. L-NMMA, a candidate suppressor of Epo expression in patients with CKD [43], is known to reduce Epo production in vitro by increasing GATA-2 DNA binding [44]. Other factors that could exert a negative tropic action on the Epo gene via increasing GATA-2 expression include TNF- $\alpha$ and NFKB. Disrupting the negative signal could prove a beneficial future tool in the management of renal anaemia. K-11706, a GATA-2-specific inhibitor, improved Epo production following inhibition by IL1- $\beta$ or TNF- $\alpha$ in Hep3B cells in vitro and in an in vivo mouse assay. Oral administration of K-11706 reversed the decreases in $\mathrm{Hb}$ and serum Epo concentrations, reticulocyte counts, and numbers of erythroid colony-forming units (CFU-Es) induced by IL1- $\beta$ or TNF- $\alpha$ [45]. These results raise the possibility of using orally administered K-11706 as an Epo supplement for treating patients with renal anaemia.

\section{HCP (SHP-1) Inhibition}

$\mathrm{rHuEpo} \mathrm{hypo-responsiveness} \mathrm{could} \mathrm{be} \mathrm{due} \mathrm{to} \mathrm{the} \mathrm{al-}$ tered gene expression profile of Epo signal transduction molecules. Recently, the role of the $s r c$ homology domain $2\left(\mathrm{SH}_{2}\right)$-containing tyrosine phosphatase-1 (SHP-1) in the pathogenesis of $\mathrm{rHuEpo}$ hypo-responsiveness has received significant attention. SHP-1, also known as haematopoietic cell phosphatase (HCP), is a protein tyrosine phosphatase located in the cytoplasm of hematopoietic cells and was originally identified in human breast carci- 
noma cDNA [46]. SHP-1 binds to the negative regulatory domain of EPOR via its src homology 2 domains and causes dephosphorylation of JAK2, thus functioning as a negative regulator of intracellular signal transduction [47]. In one study, the expression of SHP-1 by CFU-E was found to be diminished in $60 \%$ of the patients with polycythaemia vera [48]. In another study, mRNA and protein expression and tyrosine phosphorylation of SHP-1 was significantly increased in CD34+ cells derived from rHuEpo hypo-responsive haemodialysis patients compared with the rHuEpo-responsive group. In addition, the treatment of CD34+ cells from rHuEpo-hyporesponsive patients with SHP-1 antisense oligodeoxynucleotide decreased SHP-1 protein expression and upregulated STAT5, and resulted in the partial recovery of BFU-E colony formation [49]. The gene for SHP-1 has been cloned and SHP-1 inhibitors have been identified. In vitro inhibition of SHP-1 resulted in a dose-dependent erythroid proliferation [50]. Targeting SHP-1 activity in a certain group of CKD patients could be a novel method beneficial in both improving responsiveness and reducing rHuEpo requirements.

\section{Gene Therapy}

A variety of methods have been reported for experimental gene therapy. The use of Epo-secreting genetically modified fibroblasts resulted in $\mathrm{Hb}$ normalisation in Epo-deficient mice [51]. Another method could be the injection of a plasmid-encoded Epo gene into the skeletal muscle followed by electroporation (EP, gene incorporation into nuclear DNA using an intensified electric current) [52]. This method was successful in treating experimental renal anaemia in uraemic rats [53]. Epo gene transfer, using an adenovirus-associated vector (AAV), into the skeletal muscle of rats also resulted in long-term Epo expression in mice with polycystic kidney disease [54].

A hypoxia-dependent gene therapy with an AAV-carrying Epo gene, driven by HRE, has been tested in vivo. Injection of hypoxia-dependent Epo-associated AAV into hind-limb skeletal muscles of Epo-deficient mice resulted in an increase in haematocrit from 20 to $50 \%$. Interestingly, the haematocrit level stabilised without overshooting the normal ranges. That was because the promoter was switched off by the oxygenation of peripheral blood [55]. This finding could have important clinical relevance as normalisation of $\mathrm{Hb}$ without running any risk of developing secondary polycythaemia, with its possible potential serious complications, is an ideal characteristic of CKD patients.

Mifepristone (an antiprogestin) was also used in Epo gene therapy in experimental animals. Nordstrom [56] designed a plasmid-based, muscle-specific 'Gene Switch' system that was delivered to skeletal muscle by EP and provided regulated Epo expression in mice and rats in a manner that was only dependent on orally administered mifepristone. Erythropoiesis was induced (switched on) with the oral administration of a small amount of mifepristone, and after achieving the desired haematopoietic response, Epo gene expression was terminated 'switched off' by withholding oral mifepristone. Regulation was effective with low doses of mifepristone and provided regulated hematocrit changes for more than 6 months.

Takács et al. [57] made use of the ability of antigenspecific lymphocytes to undergo repeated cycles of antigen-driven clonal expansion and contraction as an elaborate tool for Epo gene delivery. They introduced genes encoding Epo into a small number of antigen-specific $B$ lymphocytes of transgenic mice. The mice were then immunised with a specific antigen, phycoerythrin, giving rise to a pool of $B$ cells that would proliferate and express Epo when stimulated by exposure to phycoerythrin. The mice were subsequently sacrificed, and lymphocytes were harvested from their spleen and lymph nodes and injected into mice with anaemia due to Epo deficiency. Serum Epo levels and haematocrit values increased in the recipient mice in response to the administration of phycoerythrin, and the time course of this response was consistent with the known kinetics of the clonal expansion of B cells in response to an antigen. Furthermore, the effect was maintained during several cycles of antigen challenge.

\section{Stimulating Erythropoiesis by Non-Epo-Related Mechanisms: PBI-1402}

PBI-1402 (created by ProMetic) is a synthetic molecule with oral bioavailability. Preclinical studies demonstrated a haematopoietic progenitor stimulator effect. Phase I trials demonstrated an efficacy comparable with Epo, GCSF and GM-CSF, and an additive effect was observed in combination with Epo, G-CSF or GM-CSF in vitro. Since PBI-1402 exerts its activity via a different mechanism(s) of action than Epo, it needs baseline endogenous Epo production to exert its effect. Therefore, it may be used as an adjuvant therapy to ESAs. Trials to assess its efficacy in treating patients with chemotherapy-induced anaemia and MDS will commence in the near future. Neverthe- 
less, preclinical studies also showed that it can correct anaemia in experimental rat models of chronic renal failure.

\section{Modifying the Route of Epo Delivery}

\section{Aerosolised Erythropoietin}

With the successful introduction of inhaled insulin (exubera) into clinical practice, attention will eventually be focused on the development of an inhalation form of Epo. Such attempts date back a few years when a naturally occurring receptor-mediated transport pathway to deliver large therapeutic proteins non-invasively was tested to assess its efficacy in delivering Epo. The normal function of the receptor, known as the neonatal Fc receptor or FcRn, is to transport immunoglobulins across cells and to protect circulating immunoglobin from degradation. In rodents, after weaning, the expression of FcRn drops precipitously and its level remains relatively low in adult rodent epithelial tissues. In humans, unlike rodents, FcRn expression remains high in certain adult tissues, specifically in epithelial cells lining the lung, kidney and intestine. Its expression in lung tissue is mainly in the central airways with very little expression in alveoli of both non-human primates and humans [58]. Dumont et al. [59] designed a molecule comprised of full-length human Epo fused recombinantly to the Fc portion of human IgG1. Using three different doses in healthy male volunteers $(3,10$ and $30 \mu \mathrm{g} / \mathrm{kg}$ ), the investigators showed dose-dependent concentrations of Fc-rHuEpo in the serum while an increase in circulating reticulocytes was only evident in the highest-dose group. This pathway could potentially be a feasible approach to drug delivery rather than using the parenteral route. The usefulness of such a method in treating anaemia of CKD has yet to be evaluated.

\section{Oral Erythropoietin}

The oral delivery of rHuEpo was also assessed in animals. In one study, mucoadhesive tablets containing Epo and an absorption enhancer (Labrasol) for oral administration were studied in rats and dogs [60]. Mucoadhesive tablets were covered with a water-insoluble backing layer and a $\mathrm{pH}$-sensitive covering layer (increases drug permeability upon contact with intestinal secretion). Theoretically, the preparation is designed to allow for the tablet to reach the small intestine intact. In one study, intrajejunal administration of a single tablet containing $100 \mathrm{IU} / \mathrm{kg}$ rHuEpo to beagle dogs showed a maximum drug concen- tration of $24.6 \pm 4.1 \mathrm{mIU} / \mathrm{ml}$. A corresponding increase in reticulocyte percentage was noted 8 days after oral administration. The oral bioavailability of rHuEpo was comparable to that of the intravenous route [60]. However, the authors did not explain how an orally administered mucoadhesive rHuEpo preparation could bypass hepatic metabolism and achieve adequate plasma levels. Such a method has not yet been assessed in humans.

\section{Non-Erythropoietic Properties of ESAs}

\section{Ischaemia-Reperfusion Injury}

In addition to modulating erythropoiesis, Epo expressed in response to hypoxia can exert an anti-apoptotic effect that can protect different organs against hypoxia-induced tissue injury. The EPOR is now known to be expressed by non-erythropoietic tissues such as neurons, astrocytes, cardiomyocytes, endothelial cells, hepatocytes and mesangial cells, to name but a few. But by far the most extensively investigated system with regard to the cytoprotective effects of rHuEpo is the nervous system. Multiple studies on models of hypoxic injury have shown that whereas Epo and EPOR are expressed in a highly restricted manner under normal brain conditions, the expression of both proteins is markedly upregulated following ischaemic and other stressor insults [61]. These findings have sparked significant enthusiasm for further investigations. Furthermore, the desire to develop a cytoprotective agent that is effective and safe has prompted attempts at designing a rHuEpo analogue that retains its anti-apoptotic/cytoprotective effect(s) but lacks its erythropoiesis-modulating effect. Creating an ultra-short-acting $\mathrm{rHuEpo}$ molecule could achieve cytoprotection without significantly affecting erythropoiesis. AsialoEpo, generated by total enzymatic desialylation of rHuEpo, possesses a very short plasma half-life (10 min after i.v., $2.5 \mathrm{~h}$ after s.c. administration) and was found to be fully neuroprotective in three different models of ischaemic/ traumatic neuronal injury [62]. Another strategy to achieve silencing erythropoiesis is carbamylation of lysines in the Epo molecule. CEpo, produced by converting all lysines in Epo molecules to homocitrulline by carbamylation [63], has been found to be cytoprotective in vitro and conferred neuroprotection against experimental models of stroke, spinal cord compression, diabetic neuropathy and experimental autoimmune encephalomyelitis at a potency and efficacy comparable to rHuEpo [63]. Also, very promising results from various animal models are increasingly suggesting a possible very relevant car- 
Table 2. Some of the registered multicenter trials testing nonerythropoietic effects of rHuEpo

\begin{tabular}{|c|c|}
\hline Condition & Drug teste \\
\hline Trauma-induced critical illness & epoetin $\alpha$ \\
\hline \multicolumn{2}{|l|}{ Chemotherapy-induced peripheral } \\
\hline neuropathy in patients with ovarian cancer & epoetin $\alpha$ \\
\hline Chronic stroke; amyotrophic lateral sclerosis & epoetin $\alpha$ \\
\hline Subarachnoid haemorrhage & epoetin $\beta$ \\
\hline Acute myocardial infarction & epoetin $\beta$ \\
\hline Cardiopulmonary bypass & epoetin $\beta$ \\
\hline Malignant spinal cord compression & epoetin $\alpha$ \\
\hline \multicolumn{2}{|l|}{ Renal transplant recipients from } \\
\hline non-heart-beating donors & epoetin $\beta$ \\
\hline Traumatic brain injury & epoetin $\alpha$ \\
\hline Sepsis & epoetin $\alpha$ \\
\hline Scuba divers & epoetin $\alpha$ \\
\hline Friedreich's ataxia & epoetin $\alpha$ \\
\hline HIV-associated neuropathy & epoetin $\alpha$ \\
\hline Paediatric cardiac surgery & epoetin $\alpha$ \\
\hline
\end{tabular}

dioprotective and nephroprotective role for ESAs, particularly for preventing/reversal of ischaemia-reperfusion injury lesions (for a comprehensive review, see Maiese et al. [64]).

It is likely that over the next decade, the cytoprotective use of rHuEpo or its analogues will come into clinical practice. At the time of submitting the manuscript for publication, of more than 45 clinical trials on rHuEpo registered with the National Institute of Health, there are more than 10 trials designed to assess the potential cytoprotective benefits of rHuEpo in various clinical settings of tissue hypoxia/injury (table 2).

\section{ESA and Cancer}

Expression of Epo and EPORs has been demonstrated in a variety of human cancers [65]. The Epo stimulation of cancer cells in vitro activates signal transduction pathways, including phosphatidylinositol 3-kinase-Akt and JAK-STAT [66]. Depending on the type of cancer, activation of the Epo/EPOR signalling axis results in measurable cellular effects, including proliferation, anti-apoptosis, and invasion [67-69]. In a recent overview that evaluated survival in 13,611 patients with cancer who were treated in 51 phase III trials, and venous thromboembolism (VTE) among 8,172 patients with cancer who were treated in 38 phase III trials, compared to no treatment, treatment with ESA was associated with a 1.57 -fold increased VTE risk and a 1.10-fold increased mortality risk
[70]. Recently, following the reporting of two further trials (one in patients with primary breast cancer receiving chemotherapy prior to surgery and the second in patients with cervical cancer treated with chemotherapy and radiation) showing increased mortality in the ESA-treated arms, the FDA strengthened its warning regarding the use of ESA in patients with cancer, restricting its use to cancer patients who develop chemotherapy-induced anaemia [71].

\section{ESA: Drug Interactions}

With the increased use of ESA in the treatment of anaemic patients with advanced heart failure, the effect of ESA is likely to be influenced by other concomitant medications. ACEI (angiotensin enzyme inhibitor) or angiotensin II (AII) receptor blocker therapy, especially at high doses, may increase the Epo requirement in dialysis patients [72]. Possible mechanisms to account for this effect include loss of AII-induced Epo release, reduction in the sensitivity to Epo, and an increase in plasma levels of the tetrapeptide $\mathrm{N}$-acetyl-seryl-aspartyl-lysyl-proline, which prevents the recruitment of pluripotent hematopoietic stem cells and normal early progenitors into the $S$-phase of the cellular cycle by maintaining them in the Go phase [73]. Anaemic patients requiring either ACEI or AII blocker therapy may require a different approach to anaemia management to optimise their response to ESA therapy.

\section{Conclusions}

Although currently available ESAs are effective in the management of CKD patients with anaemia, there are several important limitations to their effective and widespread use. There is thus still a great need for progress in this area with further drug development. While gene therapy remains in the early phases of development, third-generation agents (CERA and hematide) could simplify anaemia management and improve patient compliance relatively soon. Orally active preparations could also provide an attractive alternative/supplement to currently available agents.

It is clear that the field of renal anaemia and its treatment has come of age, but a new much more exciting and potentially useful set of agents is about to present itself to physicians and patients. If successful, with the introduction of potentially less expensive, more practical therapies, it might be possible to entertain much more widespread therapy for anaemia involving many more clinical 
settings. However, given that we have several agents that mimic human Epo and its interaction with the cell surface receptor, and that we have clear proof of efficacy, and a well-understood side effect profile derived from nearly two decades of clinical use, providing sufficient safety and outcome data for any of the non-EPO-based ESA therapies would be a challenging but very necessary hurdle before we could consider adopting a novel strategy. Even in 2008, despite two full decades of clinical use, we can get major surprises, for example, two recently published trials have examined whether full $\mathrm{Hb}$ correction, compared with standard target $\mathrm{Hb}$ values, may improve cardiovascular morbidity [74] and mortality [75] in CKD patients. Both studies were negative - indeed one suggested that in attempting to achieve a higher target (13.5 $\mathrm{g} / \mathrm{dl}$ ) there may be an increased development of adverse cardiovascular events. Despite the limitations of both studies [76], they both highlight an important fact - we still do not know enough about the remarkable compound Epo. Anaemia treatment paradigms are set to change in challenging and beneficial ways; the field is vibrant with manifold opportunities for better correction of anaemia and thereby, we hope, better health for many more patients.

\section{References}

1 de Francisco AL, Fernandez Fresnedo G, Rodrigo E, Pinera C, Heras M, Palomar R, Ruiz JC, Arias M: Past, present and future of erythropoietin use in the elderly. Int Urol Nephrol 2002;33:187-193.

$\checkmark 2$ Silverberg DS, Wexler D, Iaina A: The role of anemia in the progression of congestive heart failure: is there a place for erythropoietin and intravenous iron? J Nephrol 2004; 17:749-761.

$\checkmark 3$ Wiecek A, Mikhail A: European regulatory guidelines for biosimilars. Nephrol Dial Transplant 2006;21(suppl 5):v17-v20.

4 http://www.emea.europa.eu/humandocs/ PDFs/EPAR/epoetinalfahexal/H-726-en6. pdf. Accessed 22/4/2008.

$\checkmark 5$ Martin KJ, on behalf of the Epoetin Delta 3001 Study Group: Epoetin delta in the management of renal anaemia: results of a 6month study. Nephrol Dial Transplant 2007; 22:3052-3054.

-6 Kwan JT, Pratt RD, the Epoetin Delta Study Group: Epoetin delta, erythropoietin produced in a human cell line, in the management of anaemia in predialysis chronic kidney disease patients. Curr Med Res Opin 2007;23:307-311.

7 Bailon P, Palleroni A, Schaffer CA, Spence CL, Fung WJ, Porter JE, Ehrlich GK, Pan W, Xu ZX, Modi MW, Farid A, Berthold W, Graves M: Rational design of a potent, longlasting form of interferon: a $40 \mathrm{kDa}$ branched polyethylene glycol-conjugated interferon alpha-2a for the treatment of hepatitis C. Bioconjug Chem 2001;12:195-202.

$\checkmark 8$ Macdougall IC: CERA (continuous erythropoietin receptor activator): a new erythropoiesis-stimulating agent for the treatment of anemia. Curr Hematol Rep 2005;4:436-440.

$>$ Tillmann HC, Kuhn B, Kränzlin B, Sadick M, Gross J, Gretz N, Pill J: Efficacy and immunogenicity of novel erythropoietic agents and conventional rhEPO in rats with renal insufficiency. Kidney Int 2006;69:60-67.
0 Jarsch M, Brandt M, Lanzendorfer M, Haselbeck A: Comparative erythropoietin receptor binding kinetics of CERA and epoetinbeta determined by surface plasmon resonance and competition binding assay. Pharmacology 2007;81:63-69.

11 Bunn HF: New agents that stimulate erythropoiesis. Blood 2007;109:868-873. Epub 10 Oct 2006.

12 Macdougall IC, Robson R, Opatrna S, Liogier X, Pannier A, Jordan P, Dougherty FC, Reigner B: Pharmacokinetics and pharmacodynamics of intravenous and subcutaneous continuous erythropoietin receptor activator (CERA) in patients with chronickidney disease. Clin J Am Soc Nephrol 2006;1:12111215.

13 Provenzano R, Besarab A, Macdougall IC, Ellison DH, Maxwell AP, Sulowicz W, Klinger M, Rutkowski B, Correa-Rotter R, Dougherty FC, BA 16528 Study Investigators: The continuous erythropoietin receptor activator (CERA) corrects anemia at extended administration intervals in patients with chronic kidney disease not on dialysis: results of a phase II study. Clin Nephrol 2007; 67:306-317.

14 de Francisco AL, Sulowicz W, Klinger M, Niemczyk S, Vargemezis V, Metivier F, Dougherty FC, Oguey D, BA16260 Study Invesigators: Continuous erythropoietin receptor activator (CERA) administered at extended administration intervals corrects anaemia in patients with chronic kidney disease on dialysis: a randomised, multicentre, multiple-dose, phase II study. Int J Clin Pract 2006;60:1687-1696. Erratum in: Int J Clin Pract 2007;61:1776-1777.
Sulowicz W, Locatelli F, Ryckelynck JP, Balla J, Csiky B, Harris K, Ehrhard P, Beyer U, PROTOS Study Investigators: Once-monthly subcutaneous CERA maintains stable hemoglobin control in patients with chronic kidney disease on dialysis and converted directly from epoetin one to three times weekly. Clin J Am Soc Nephrol 2007;2:637-646.

16 Macdougall IC, Walker R, Provenzano R, de Alvaro F, Locay HR, Nader PC, Locatelli F, Dougherty FC, Beyer U, ARCTOS Study Investigators: CERA corrects anemia in patients with chronic kidney disease not on dialysis: results of a randomized clinical trial. Clin J Am Soc Nephrol 2008;3:337-347.

17 Webster R, Didier E, Harris P, Siegel N, Stadler J, Tilbury L, Smith D: PEGylated proteins: evaluation of their safety in the absence of definitive metabolism studies. Drug Metab Dispos 2007;35:9-16.

18 Wrighton NC, Farrell FX, Chang R, Kashyap AK, Barbone FP, Mulcahy LS, Johnson DL, Barrett RW, Jolliffe LK, Dower WJ: Small peptides as potent mimetics of the protein hormone erythropoietin. Science 1996;273: 458-464.

19 Stead RB, Lambert J, Wessels D, Iwashita JS, Leuther KK, Woodburn KW, Schatz PJ, Okamoto DM, Naso R, Duliege AM: Evaluation of the safety and pharmacodynamics of hematide, a novel erythropoietic agent, in a phase 1, double-blind, placebo-controlled, dose-escalation study in healthy volunteers. Blood 2006;108:1830-1834.

20 Macdougall I, Tucker B, Yaqoob M, Mikhail A, Nowicki M, MacPhee I, Mysliwiec M, Sulowicz W, Zamauskaite A, Leong R, Iwashita J, Duliege AM, Wiecek A: Hematide, a synthetic peptide-based erythropoiesis stimulating agent (ESA), achieves correction of anemia and maintains hemoglobin ( $\mathrm{Hb}$ ) in patients with chronic kidney disease (CKD) (abstract F-FC079). J Am Soc Nephrol 2006; 17:35A. 
21 Johnson DL, Jolliffe LK: Erythropoietin mimetic peptides and the future. Nephrol Dial Transplant 2000;15:1274-1277.

-22 Sytkowski AJ, Lunn ED, Risinger MA, Davis KL: An erythropoietin fusion protein comprised of identical repeating domains exhibits enhanced biological properties. J Biol Chem 1999;274:24773-24778.

23 Coscarella A, Liddi R, Bach S, Zappitelli S, Urso R, Mele A, De Santis R: Pharmacokinetic and immunogenic behavior of three recombinant human GM-CSF-EPO hybrid proteins in cynomolgus monkeys. Mol Biotechnol 1998;10:115-122.

-24 Coscarella A, Liddi R, Di Loreto M, Bach S, Faiella A, van der Meide PH, Mele A, De Santis R: The rhGM-CSF-EPO hybrid protein MEN 11300 induces anti-EPO antibodies and severe anaemia in rhesus monkeys. Cytokine 1998; 10:964-969.

25 Capon DJ, Chamow SM, Mordenti J, Marsters SA, Gregory T, Mitsuya H, Byrn RA, Lucas C, Wurm FM, Groopman JE, et al: Designing CD4 immunoadhesins for AIDS therapy. Nature 1989;337:525-531.

26 Yeh P, Landais D, Lemaitre M, Maury I, Crenne JY, Becquart J, Murry-Brelier A, Boucher F, Montay G, Fleer R, et al: Design of yeast-secreted albumin derivatives for human therapy: biological and antiviral properties of a serum albumin-CD4 genetic conjugate. Proc Natl Acad Sci USA 1992;89: 1904-1908

-27 Bugelski P, Nesspor BT, Spinka-Doms T, Markopoulos D, Eirikis E, Fisher J, Volk A, Shamberger K, James I, Fisher P, Pool C, Jang H, Miller B, Huang C, Heavner G, Knight D, Ghrayeb J, Scallon B: Pharmacokinetics and pharmacodynamics of CTNO528, a novel erythropoiesis receptor agonist in normal and anaemic rats (abstract 4261). Blood 2005; 106:146b.

28 Franson KL, Burggraaf, Bouman-Trio EA, Cohen AF, Miller BE, Jang H, Marciniak SL, van de Ketterij EPS, Frederick b, Jiao Q, Getsy J, Bald EH, Walker H, Schantz A, Ford JA, Mascioli K, Kowalchick JB: A phase I, single and fractionated, ascending dose study evaluating the safety, pharmacokinetics, pharmakodynamics, and immunogenicity of an erythropoietic mimetic antibody fusion protein, CTNO528 in healthy male subjects (abstract 4283). Blood 2005;106:146b.

29 Jelkmann W: Erythropoietin: structure, control of production, and function. Physiol Rev 1992;72:449-489.

30 Semenza GL: Surviving ischemia: adaptive responses mediated by hypoxia-inducible factor 1. J Clin Invest 2000;106:809-812.

- 31 Pugh CW, Ratcliffe PJ: Regulation of angiogenesis by hypoxia: role of the HIF system. Nat Med 2003;9:677-684.
32 Ang SO, Chen H, Hirota K, Gordeuk VR, Jelinek J, Guan Y, Liu E, Sergueeva AI, Miasnikova GY, Mole D, Maxwell PH, Stockton DW, Semenza GL, Prchal JT: Disruption of oxygen homeostasis underlies congenital Chuvash polycythemia. Nat Genet 2002;32: 614-621.

33 Liu E, Percy MJ, Amos CI, Guan Y, Shete S, Stockton DW, McMullin MF, Polyakova LA Ang SO, Pastore YD, Jedlickova K, Lappin TR, Gordeuk V, Prchal JT: The worldwide distribution of the VHL 598C $>$ T mutation indicates a single founding event. Blood 2004;103:1937-1940.

- 34 Gordeuk VR, Sergueeva AI, Miasnikova GY, Okhotin D, Voloshin Y, Choyke PL, Butman JA, Jedlickova K, Prchal JT, Polyakova LA: Congenital disorder of oxygen sensing: association of the homozygous Chuvash polycythemia VHL mutation with thrombosis and vascular abnormalities but not tumors. Blood 2004;103:3924-3932.

35 Lonser RR, Glenn GM, Walther M, et al: von Hippel-Lindau disease. Lancet 2003;361: 2059-2067.

36 Clifford SC, Cockman ME, Smallwood AC, et al: Contrasting effects on HIF-1alpha regulation by disease-causing pVHL mutations correlate with patterns of tumourigenesis in von Hippel-Lindau disease. Hum Mol Genet 2001;10:1029-1038.

37 Guenzler V, Muthukrishnan E, Neumayer $\mathrm{HH}$, Sacherer K, Schmidt R, Mitzner A, Wiecek A, Piecha G, Ignacy W, Scigalla P: FG-2216 increases hemoglobin concentration in anemic patients with chronic kidney disease (abstract SA-PO924). J Am Soc Nephrol 2005;16:758A.

38 Klaus S, Arend M, Fourney P, Flippin L, Gervasi $D$, Guenzler V, Kochendoerfer G, Langsetmo I, Lin A, McDaniel D, Meier-Davis S, Seeley T, Spong S, Liu DY: Induction of erythropoiesis and iron utilization by the HIF prolyl hydroxylase inhibitor FG-4592 (abstract F-FC050). J Am Soc Nephrol 2005 16:49A.

39 Ferreira R, Ohneda K, Yamamoto M, Philipsen S: GATA1 function, a paradigm for transcription factors in hematopoiesis. Mol Cell Biol 2005;25:1215-1227.

40 Weiss MJ, Keller G, Orkin SH: Novel insights into erythroid development revealed through in vitro differentiation of GATA-1 embryonic stem cells. Genes Dev 1994;8: 1184-1197.

41 Tsai FY, Orkin SH: Transcription factor GATA-2 is required for proliferation/survival of early hematopoietic cells and mast cell formation, but not for erythroid and myeloid terminal differentiation. Blood 1997;89: 3636-3643.

42 Imagawa S, Yamamoto M, Miura Y: Negative regulation of the erythropoietin gene expression by the GATA transcription factors. Blood 1997;89:1430-1439.
43 Imagawa S, Tarumoto T, Suzuki N, Mukai HY, Hasegawa Y, Higuchi M, Neichi T, Ozawa K, Yamamoto M, Nagasawa T: L-Arginine rescues decreased erythropoietin gene expression by stimulating GATA-2 with LNMMA. Kidney Int 2002;61:396-404

-44 Tarumoto T, Imagawa S, Ohmine K, Nagai T, Higuchi M, Imai N, Suzuki N, Yamamoto M, Ozawa K: N(G)-monomethyl-L-arginine inhibits erythropoietin gene expression by stimulating GATA-2. Blood 2000;96:17161722.

45 Nakano Y, Imagawa S, Matsumoto K, Stockmann C, Obara N, Suzuki N, Doi T, Kodama T, Takahashi S, Nagasawa T, Yamamoto M: Oral administration of K-11706 inhibits GATA binding activity, enhances hypoxiainducible factor 1 binding activity, and restores indicators in an in vivo mouse model of anemia of chronic disease. Blood 2004; 104:4300-4307.

-46 Shen SH, Bastien L, Posner BI, Chretien P: A protein-tyrosine phosphatase with sequence similarity to the $\mathrm{SH} 2$ domain of the proteintyrosine kinases. Nature 1991;352:736-739. Erratum in: Nature 1991;353:868.

47 Klingmüller U, Lorenz U, Cantley LC, Neel BG, Lodish HF: Specific recruitment of SHPTP1 to the erythropoietin receptor causes inactivation of JAK2 and termination of proliferative signals. Cell 1995;80:729-738.

48 Wickrema A, Chen F, Namin F, Yi T, Ahmad S, Uddin S, Chen YH, Feldman L, Stock W, Hoffman R, Platanias LC: Defective expression of the SHP-1 phosphatase in polycythemia vera. Exp Hematol 1999;27:1124-1132.

49 Akagi S, Ichikawa H, Okada T, Sarai A, Sugimoto T, Morimoto $\mathrm{H}$, Kihara T, Yano A, Nakao K, Nagake Y, Wada J, Makino H: The critical role of SRC homology domain 2-containing tyrosine phosphatase- 1 in recombinant human erythropoietin hyporesponsive anemia in chronic hemodialysis patients. J Am Soc Nephrol 2004;15:3215-3224.

50 Barbone FP, Johnson DL, Farrell FX, Collins A, Middleton SA, McMahon FJ, Tullai J, Jolliffe LK: New epoetin molecules and novel therapeutic approaches. Nephrol Dial Transplant 1999;14(suppl 2):80-84.

-51 Rinsch C, Dupraz P, Schneider BL, Deglon N, Maxwell PH, Ratcliffe PJ, Aebischer P: Delivery of erythropoietin by encapsulated myoblasts in a genetic model of severe anemia. Kidney Int 2002;62:1395-1401.

52 Rizzuto G, Cappelletti M, Mennuni C, Wiznerowicz M, DeMartis A, Maione D, Ciliberto G, La Monica N, Fattori E: Gene electrotransferresultsinahigh-leveltransduction of rat skeletal muscle and corrects anemia of renal failure. Hum Gene Ther 2000;11:18911900

53 Maruyama H, Ataka K, Higuchi N, Sakamoto F, Gejyo F, Miyazaki J: Skin-targeted gene transfer using in vivo electroporation. Gene Ther 2001;8:1808-1812. 
-54 Osada S, Ebihara I, Setoguchi Y, Takahashi $\mathrm{H}$, Tomino Y, Koide H: Gene therapy for renal anemia in mice with polycystic kidney using an adenovirus vector encoding the human erythropoietin gene. Kidney Int 1999; 55:1234-1240.

55 Binley K, Askham Z, Iqball S, Spearman H, Martin L, de Alwis M, Thrasher AJ, Ali RR, Maxwell PH, Kingsman S, Naylor S: Longterm reversal of chronic anemia using a hypoxia-regulated erythropoietin gene therapy. Blood 2002;100:2406-2413.

-56 Nordstrom JL: The antiprogestin-dependent Gene Switch system for regulated gene therapy. Steroids 2003;68:1085-1094.

- 57 Takács K, Du Roure C, Nabarro S, Dillon N, McVey JH, Webster Z, Macneil A, Bartok I, Higgins C, Gray D, Merkenschlager M, Fisher AG: The regulated long-term delivery of therapeutic proteins by using antigen-specific B lymphocytes. Proc Natl Acad Sci USA 2004;101:16298-16303.

58 Spiekermann GM, Finn PW, Ward ES, Dumont J, Dickinson BL, Blumberg RS, Lencer WI: Receptor-mediated immunoglobulin G transport across mucosal barriers in adult life: functional expression of FcRn in the mammalian lung. J Exp Med 2002;196:303310. Erratum in: J Exp Med 2003;197:1601.

59 Dumont JA, Bitonti AJ, Clark D, Evans S, Pickford M, Newman SP: Delivery of an erythropoietin-Fc fusion protein by inhalation in humans through an immunoglobulin transport pathway. J Aerosol Med 2005;18: 294-303.

60 Venkatesan N, Yoshimitsu J, Ohashi Y, Ito Y, Sugioka N, Shibata N, Takada K: Pharmacokinetic and pharmacodynamic studies following oral administration of erythropoietin mucoadhesive tablets to beagle dogs. Int J Pharm 2006;310:46-52.

61 Brines M, Cerami A: Discovering erythropoietin's extra-hematopoietic functions: biology and clinical promise. Kidney Int 2006; 70:246-250.
62 Erbayraktar S, Grasso G, Sfacteria A, Xie QW, Coleman T, Kreilgaard M, Torup L, Sager T, Erbayraktar Z, Gokmen N, Yilmaz O, Ghezzi P, Villa P, Fratelli M, Casagrande S, Leist M, Helboe L, Gerwein J, Christensen S, Geist MA, Pedersen L $\varnothing$, Cerami-Hand C, Wuerth JP, Cerami A, Brines M: Asialoerythropoietin is a nonerythropoietic cytokine with broad neuroprotective activity in vivo. Proc Natl Acad Sci USA 2003;100: 6741-6746.

63 Leist M, Ghezzi P, Grasso G, Bianchi R, Villa P, Fratelli M, Savino C, Bianchi M, Nielsen J, Gerwien J, Kallunki P, Larsen AK, Helboe L, Christensen S, Pedersen LO, Nielsen M, Torup L, Sager T, Sfacteria A, Erbayraktar S, Erbayraktar Z, Gokmen N, Yilmaz O, Cerami-Hand C, Xie QW, Coleman T, Cerami A, Brines M: Derivatives of erythropoietin that are tissue protective but not erythropoietic. Science 2004;305:239-242.

64 Maiese K, Li F, Chong ZZ: New avenues of exploration for erythropoietin. JAMA 2005; 293:90-95.

65 Hardee ME, Arcasoy MO, Blackwell KL, Kirkpatrick JP, Dewhirst MW: Erythropoietin biology in cancer. Clin Cancer Res 2006; 12:332-339.

66 Hardee ME, Rabbani ZN, Arcasoy MO, Kirkpatrick JP, Vujaskovic Z, Dewhirst MW, Blackwell KL: Erythropoietin inhibits apoptosis in breast cancer cells via an Akt-dependent pathway without modulating in vivo chemosensitivity. Mol Cancer Ther 2006;5: 356-361.

67 Acs G, Acs P, Beckwith SM, et al: Erythropoietin and erythropoietin receptor expression in human cancer. Cancer Res 2001;61: 3561-3565.

68 Lai SY, Childs EE, Xi S, Coppelli FM, Gooding WE, Wells A, Ferris RL, Grandis JR: Erythropoietin-mediated activation of JAKSTAT signaling contributes to cellular invasion in head and neck squamous cell carcinoma. Oncogene 2005;24:4442-4449.
69 Kumar SM, Yu H, Fong D, Acs G, Xu X: Erythropoietin activates the phosphoinositide 3-kinase/Akt pathway in human melanoma cells. Melanoma Res 2006;16:275283.

70 Bennett CL, Silver SM, Djulbegovic B, Samaras AT, Blau CA, Gleason KJ, Barnato SE, Elverman KM, Courtney DM, McKoy JM, Edwards BJ, Tigue CC, Raisch DW, Yarnold PR, Dorr DA, Kuzel TM, Tallman MS, Trifilio SM, West DP, Lai SY, Henke M: Venous thromboembolism and mortality associated with recombinant erythropoietin and darbepoetin administration for the treatment of cancer-associated anemia. JAMA 2008;299: 914-924.

71 http://www.fda.gov/cder/drug/early_ comm/ESA.htm. Accessed 22/4/2008.

$>72$ Albitar S, Genin R, Fen-Chong M, Serveaux MO, Bourgeon B: High dose enalapril impairs the response to erythropoietin treatment in haemodialysis patients. Nephrol Dial Transplant 1998;13:1206-1210.

73 Azizi M, Rousseau A, Ezan E, Guyene TT, Michelet S, Grognet JM, Lenfant M, Corvol $\mathrm{P}$, Ménard J: Acute angiotensin-converting enzyme inhibition increases the plasma level of the natural stem cell regulator $\mathrm{N}$-acetylseryl-aspartyl-lysyl-proline. J Clin Invest 1996;97:839-844.

74 Drueke TB, Locatelli F, Clyne N, Eckardt KU, Macdougall IC, Tsakiris D, Burger HU, Scherhag A, CREATE Investigators: Normalization of hemoglobin level in patients with chronic kidney disease and anemia. N Engl J Med 2006;355:2071-2084.

75 Singh AK, Szczech L, Tang KL, Barnhart H, Sapp S, Wolfson M, Reddan D, CHOIR Investigators: Correction of anemia with epoetin alfa in chronic kidney disease. N Engl J Med 2006;355:2085-2098.

76 Levin A: Understanding recent haemoglobin trials in CKD: methods and lesson learned from CREATE and CHOIR. Nephrol Dial Transplant 2007;22:309-312. 